\title{
MECHANICAL PROPERTIES OF PLASMA-SPRAYED LAYERS OF ALUMINIUM AND ALUMINIUM ALLOY ON AZ 91
}

\author{
MEHANSKE LASTNOSTI S PLAZMO NANEŠENIH PLASTI \\ ALUMINIJA IN ALUMINIJEVE ZLITINE NA AZ 91
}

\author{
Tomáš František Kubatík, Pavel Ctibor, Radek Mušálek, Marek Janata \\ Institute of Plasma Physics CAS, v.v.i., Za Slovankou 1782/3, 18200 Prague, Czech Republic \\ kubatik@ipp.cas.cz \\ Prejem rokopisa - received: 2015-10-29; sprejem za objavo - accepted for publication: 2016-02-09
}

doi: $10.17222 / \mathrm{mit} .2015 .326$

\begin{abstract}
Magnesium alloys are promising materials thanks to their high specific strength and stiffness. However, their wide application is discouraged by their low resistance to wear and very low resistance to corrosion. Plasma-spraying technology makes it possible to prepare protective metal and non-metal coatings. In this work, $450 \mu \mathrm{m}$ thick and $490 \mu \mathrm{m}$ thick plasma-spray coatings of commercially pure (CP) aluminium and aluminium alloy AlCr6Fe2 were prepared on magnesium alloy AZ91. The adhesion strength of plasma-sprayed aluminium was about $19 \mathrm{MPa}$, while the aluminium alloy showed an adhesion strength of about $12 \mathrm{MPa}$. Plasma-sprayed coatings improved the wear resistance of the AZ91 surface up to four times.

Keywords: plasma spraying of aluminum, adhesion of coating, wear, magnesium alloy AZ91
\end{abstract}

Magnezijeve zlitine so obetajoč material, zahvaljujoč njihovi veliki specifični trdnosti in togosti. Vendar pa njihovo široko uporabo zavira majhna odpornost na obrabo in zelo slaba korozijska odpornost. Tehnologija plazemskega nabrizgavanja omogoča izdelavo zaščitnih kovinskih in nekovinskih nanosov. V tem delu so bili pripravljeni plazemsko nabrizgani, $450 \mu \mathrm{m}$ in $490 \mu \mathrm{m}$ debeli nanosi komercialno čistega (CP) aluminija in aluminijeve zlitine AlCr6Fe2 na magnezijevi zlitini AZ91. Adhezijska trdnost plazemsko nabrizganega aluminija je bila okrog $19 \mathrm{MPa}$, aluminijeva zlitina je pokazala adhezijsko trdnost okrog $12 \mathrm{MPa}$. Plazemsko nabrizgani nanosi so izboljšali obrabno odpornost zlitine AZ91 za 4x.

Ključne besede: plazemsko nabrizgavanje aluminija, adhezija nanosa, obraba, magnezijeva zlitina AZ91

\section{INTRODUCTION}

Magnesium and its alloys have an excellent ratio of density and strength; they are suitable for lightweight construction in the automotive and aerospace industries, and also for bio-medical applications due to their high specific strength and stiffness., ${ }^{1,2}$ Magnesium and magnesium alloys are very susceptible to galvanic corrosion, which can result in severe pitting, especially in a wet and salty environment. This disadvantage can be utilized in biomedicine for endoprosthetics, which may dissolve at a controlled speed. ${ }^{3}$ Alloying of magnesium with aluminium or manganese can improve not only its mechanical properties but also the corrosion resistance. Aluminium in the contents of $4-9 \%$ by weight can rapidly improve the corrosion resistance thanks to the formation of the intermetallic phase $\mathrm{Mg}_{17} \mathrm{Al}_{12}$, which precipitates along the grain boundaries and serves as a corrosion barrier. ${ }^{4}$ Magnesium and its alloys can be also protected by a deposition of surface-protective coatings. There are several technologies for producing protective coatings, metal and non-metal ones (in particular the technology of plasma spraying) making it possible to prepare anticorrosion coatings, improving the surface abrasive resistance as well as the hardness. In references $^{5-8}$ the authors devote their studies to the plasmasprayed coatings of aluminium, $\mathrm{NiAl} 5$ and $\mathrm{Al}_{2} \mathrm{O}_{3}$ on the magnesium alloy AZ91. ${ }^{8}$ Plasma spraying of pure $\mathrm{Al}$ on the AZ 91 alloy provided coating adhesion strengths of 6-12 MPa, and when spraying NiAl5 on the AZ91 alloy, the adhesion strengths of 17-25 MPa were reported. ${ }^{8}$ This work deals with the study of mechanical properties, the adhesion strength and the resistance to wear of the coatings made of commercially pure (CP) aluminium and an alloy thermally stable up to $300{ }^{\circ} \mathrm{C}$, i.e., $\mathrm{AlCr} 6 \mathrm{Fe} 2^{9}$ on the magnesium alloy AZ 91 using a hybrid water-stabilized plasma torch WSP-H $500^{\circ}$ which potentially provides a rather high throughput for spraying large areas.

\section{EXPERIMENTAL PART}

Two powders were used as a feedstock for plasma spraying using a hybrid water-stabilized torch WSP-H $500^{\odot}$ (Institute of Plasma Physics CAS, v.v.i, CZ) operated at the power of $160 \mathrm{~kW}$, namely, a commercially pure $(\mathrm{CP})$ aluminium powder with grain sizes from $45 \mu \mathrm{m}$ to $90 \mu \mathrm{m}$ and aluminium alloy AlCr6Fe2 (ICTPrague, CZ) with grain sizes from $80 \mu \mathrm{m}$ to $180 \mu \mathrm{m}$. The aluminium alloy powder was prepared with the atomization of the melted aluminium alloy AlCr6Fe2 using compressed Ar and the subsequent sieving to achieve the proper fraction. During plasma spraying, the powder in the quantity of $110 \mathrm{~g} / \mathrm{min}$ was injected with compressed 
air into the plasma jet, and the spraying distance was 330 $\mathrm{mm}$. The substrates of $(70 \times 20 \times 5) \mathrm{mm}$ were manufactured from magnesium alloy AZ91. Prior to plasma spraying, the substrates were grit blasted with alumina grit and degreased in acetone. The original feedstock powder as well as both the free surface and the metallographic cross-sections of the sprayed layers were observed with a scanning electron microscope EVO MA 15 (Carl Zeiss SMT, D). The cylindrical specimens (the substrate of magnesium alloy AZ91) with a diameter of $25 \mathrm{~mm}$, a height of $50 \mathrm{~mm}$ and with an impassable tapped screw M10 were prepared for the evaluation of the coating adhesion strength, which was conducted in accordance with the ASTM C 633 standard. The coating deposition was carried out on the blasted cylinder ends with a roughness of approximately $\mathrm{Ra} 9.5 \mu \mathrm{m}$, preheated to $180{ }^{\circ} \mathrm{C}$ and with a target thicknesses of approximately $500 \mu \mathrm{m}$. This thickness guaranteed that the coating-adhesion test was not influenced by the glue penetrating into the coating microstructure. ${ }^{10}$ The counterpart, i.e., a steel cylinder of the same dimensions, was glued with the heat-hardenable one-component epoxy adhesive E1100S (Gupex, UK) on the plasmacoated surface. After the heat hardening of the adhesive, tension tests were conducted using an Instron 1362 (Instron, UK) electro-mechanical tensile testing machine. The presented adhesion-strength result is the average of six measurements.

Table 1: Average values of the adhesion strength for $\mathrm{CP}-\mathrm{Al}$ and aluminium alloy

Tabela 1: Povprečna vrednost adhezijske trdnosti za $\mathrm{CP}-\mathrm{Al}$ in aluminijevo zlitino

\begin{tabular}{|c|c|}
\hline Sample & Adhesion strength \\
\hline CP-aluminium coating & $18.94 \pm 1.29 \mathrm{MPa}$ \\
\hline Aluminium-alloy coating & $12.15 \pm 1.22 \mathrm{MPa}$ \\
\hline
\end{tabular}

In order to obtain a compact reference sample for abrasive-wear testing, the feedstock powders, used for

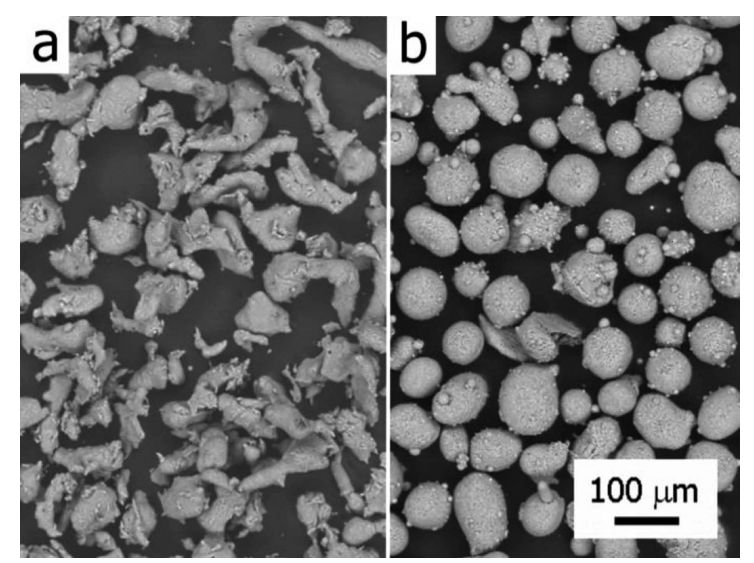

Figure 1: Feedstock powder: a) aluminium $\mathrm{CP}-\mathrm{Al}$, fraction $90+45$ $\mu \mathrm{m}$, b) aluminium alloy AlCr6Fe2, fraction $180+80 \mu \mathrm{m}(\mathrm{SEM}-$ BSE)

Slika 1: Izhodni prah: a) aluminij CP-Al $-90+45 \mu \mathrm{m}$ frakcija, b) aluminijeva zlitina AlCr6Fe2, frakcija $180+80 \mu \mathrm{m}$ (SEM - BSE) plasma spraying, were sintered by means of the sparkplasma-sintering (SPS) technique. ${ }^{11}$ The sintering began with evacuation of the chamber. Afterwards, the sample was pre-loaded to $20 \mathrm{MPa}$, followed by heating with a rate of $100{ }^{\circ} \mathrm{C} / \mathrm{min}$. After reaching the desired sintering temperature of $550{ }^{\circ} \mathrm{C}$, the sample was loaded with the final compression pressure of $80 \mathrm{MPa}$. The dwell time at this temperature and pressure was $5 \mathrm{~min}$. After the dwell time, the DC pulse source was turned off and the sample was cooled down to the room temperature by free cooling. After aeration of the chamber, the sample was removed from the graphite tool.

The wear resistance of the samples was evaluated by the slurry abrasion response (SAR) test following the ASTM standard. ${ }^{12}$ The test was carried out in four increments (runs) with the mass loss being measured at the end of each run. The applied force was $22 \mathrm{~N}$ per specimen. In the case of the studied materials, the runs were shortened to one quarter of the standard duration because of the relatively low thickness and resistance of the coatings. After each run, the specimens were ultrasonically cleaned, dried and weighted. The slurry consisted of $150 \mathrm{~g}$ of organic oil (the water recommended in the ASTM standard had to be avoided because of its reactivity with the studied materials) and $150 \mathrm{~g}$ of alumina powder with a size of $40-50 \mu \mathrm{m}$. The accuracy of the measurement is typically $\pm 5 \% .{ }^{12}$

Microhardness was measured using a Hanemann microhardness head (Zeiss, Germany) mounted on an optical microscope with a fixed load of $0.5 \mathrm{~N}$ and a Vickers indenter. Twenty indentations made at randomly selected spots on the cross-section of each sample were analyzed.

\section{RESULTS AND DISCUSSION}

\subsection{Microstructure}

Figure 1 depicts the microstructures of the used powders: a) $\mathrm{CP}$ aluminium and b) aluminium alloy

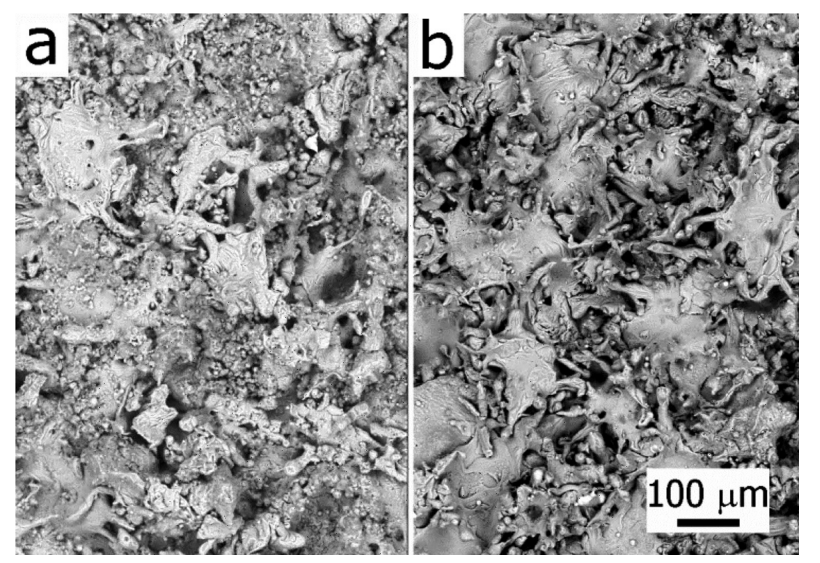

Figure 2: Free surface of the layer prepared with plasma spraying: a) aluminium powder CP-Al and b) aluminium alloy (SEM - BSE)

Slika 2: Prosta površina nanosa, izdelanega s plazemskim naprševanjem: a) aluminija v prahu CP-Al in b) aluminijeva zlitina (SEM BSE) 
T. F. KUBATÍK et al.: MECHANICAL PROPERTIES OF PLASMA-SPRAYED LAYERS OF ALUMINIUM AND ...

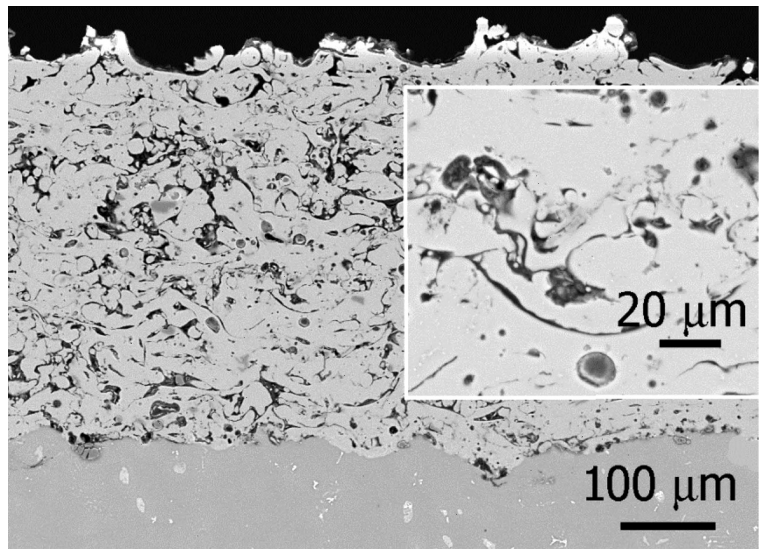

Figure 3: Microstructure of the cross-section of $\mathrm{CP}-\mathrm{Al}$ sprayed on magnesium alloy AZ 91 (SEM - BSE)

Slika 3: Mikrostruktura prereza nabrizganega CP-Al na magnezijeve zlitine AZ91 (SEM - BSE)

AlCr6Fe2. It can be seen that the used aluminium powder on Figure 1a was of an irregular shape, most often consisting of elongated straight or twisted particles. The aluminium alloy from Figure 1b consisted of regular spherical particles with the mean size of about 100 micrometers. It is also visible on Figure 2a that the surface of the sprayed coatings is mainly composed of irregular splats and small spherical particles. In the case of the aluminium alloy from Figure $\mathbf{2 b}$ the surface is dominantly composed of irregular splats.

Figure 3 shows the cross-sectional microstructure of the plasma coating of $\mathrm{CP}$ aluminium on magnesium alloy AZ 91. The microstructure is typical for plasmasprayed metallic coating sprayed in an open-air atmosphere, containing splats, spherical particles and pores. The layer was prepared using plasma spraying with the average thickness of $448 \pm 31 \mu \mathrm{m}$. The plasma-sprayed layer of the aluminium alloy on magnesium alloy AZ-91 is shown in Figure 4. The layer contains large particles and splats because almost a double grain size of the

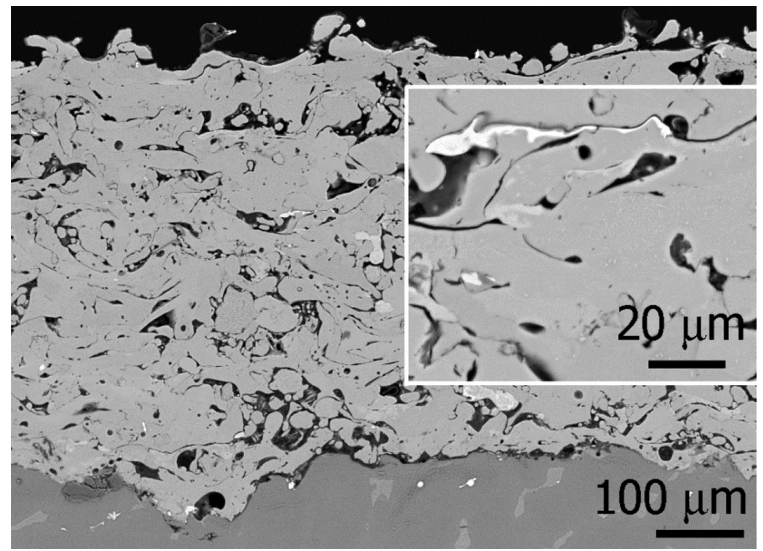

Figure 4: Microstructure of the cross-section of the aluminium alloy sprayed on magnesium alloy AZ 91 (SEM - BSE)

Slika 4: Mikrostruktura prereza aluminijeve zlitine nabrizgane na magnezijevo zlitino AZ91 (SEM - BSE)

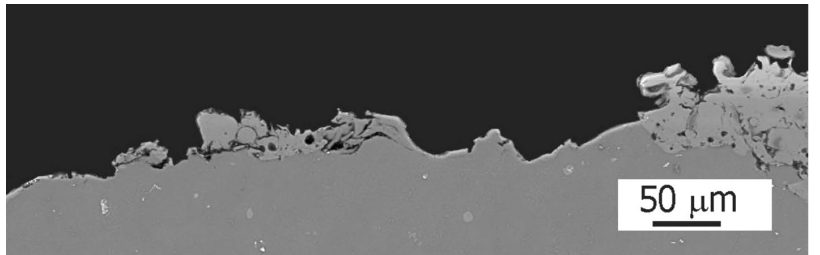

Figure 5: Residue of CP-Al coating on AZ 91 after the adhesion test (SEM - BSE)

Slika 5: Ostanki CP-Al nanosa na AZ91 po preizkusu adhezije (SEMBSE)

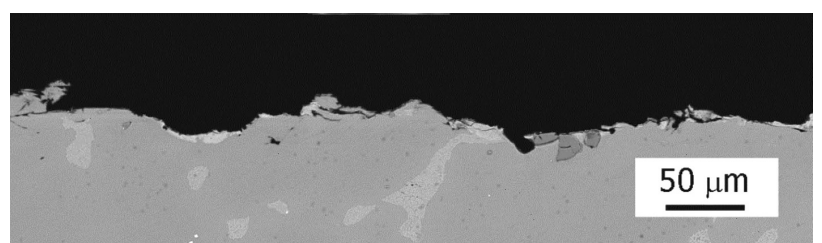

Figure 6: Residue of aluminium alloy coating on AZ 91 after the adhesion test (SEM - BSE)

Slika 6: Ostanki aluminijeve zlitine na AZ91 po preizkusu adhezije (SEM - BSE)

powder was used. The prepared layer has an average thickness of $489 \pm 26 \mu \mathrm{m}$.

\subsection{Adhesion testing}

The average value of the tensile adhesion strength of CP Al coating is $18.94 \pm 1.29 \mathrm{MPa}$, and the one of the aluminum alloy is $12.15 \pm 1.22 \mathrm{MPa}$. In the case of $\mathrm{CP} \mathrm{Al}$ coatings, all samples were fractured near the coatingsubstrate (Figure 5) interface in combined cohesion/ adhesion failure. In the case of $\mathrm{Al}$ alloy coating on AZ91, the whole layer was detached from the surface at the substrate-coating interface in all six measured samples (adhesion failure of Al alloy coating, crosssection, Figure 6). The values of adhesion strength for $\mathrm{CP}$ aluminium coating ranging from 17 to $20.5 \mathrm{MPa}$ are significantly higher than in the case of the strength of $\mathrm{Al}$

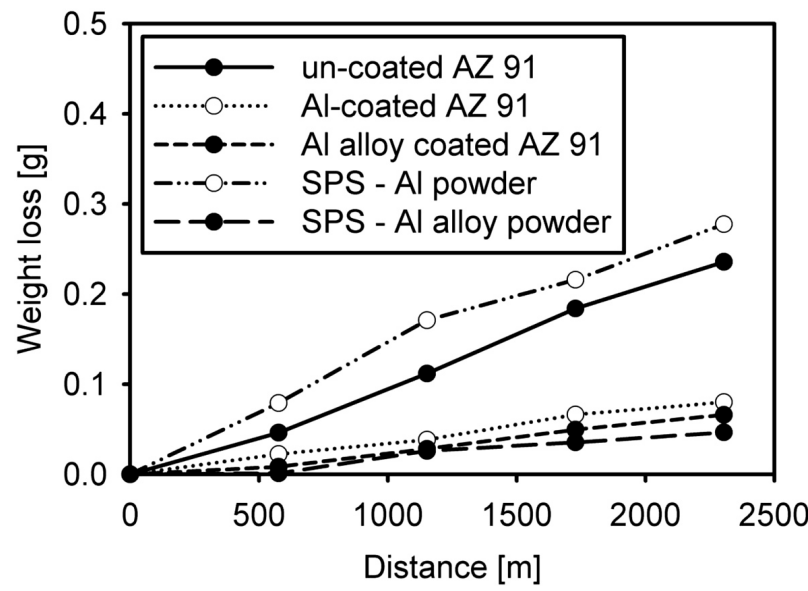

Figure 7: SAR test result, weight-loss dependence on the travel distance

Slika 7: Rezultati SAR-preizkusa, odvisnost izgube teže od dolžine poti 


\section{T. F. KUBATÍK et al.: MECHANICAL PROPERTIES OF PLASMA-SPRAYED LAYERS OF ALUMINIUM AND ...}

alloy coatings, and also higher than published by Maria Parco et al., ${ }^{8}$ who published values ranged from $6 \mathrm{MPa}$ to $12 \mathrm{MPa}$ for the substrate without pre-heating, and adhesion strength of $15 \mathrm{MPa}$ for the substrate preheated to $160{ }^{\circ} \mathrm{C}$ and with a blasted surface.

The results of the wear-resistance measurement, namely, the dependence of mass losses for path lengths $(576,1152,1728$ and 2304) $\mathrm{m}$, are plotted in the graph in Figure 7. The results of the wear-resistance measurement are in line with the expectations, i.e., the SPS-sintered pure aluminium showed the highest wear loss followed by the uncoated magnesium alloy AZ 91. It is clearly visible in the graph that both plasma coatings have an improved wear resistance of the substrate material (AZ 91). The best results are achieved when aluminium alloy is used as a coating, and the wear values within the distance of $1152 \mathrm{~m}$ are similar to those of the sintered aluminium alloy. The sintered aluminium alloy, followed by the aluminium-alloy coating, are the most resistant to wear for the whole path. The measured roughness is listed in Table 2. The roughness is rather high for the as-sprayed coatings but after $576 \mathrm{~m}$ of the wear test, it is greatly reduced and not changed significantly during the further wear testing. The compact sintered aluminium alloy is tougher and more resistant to abrasion and there is a similar effect of the plasma

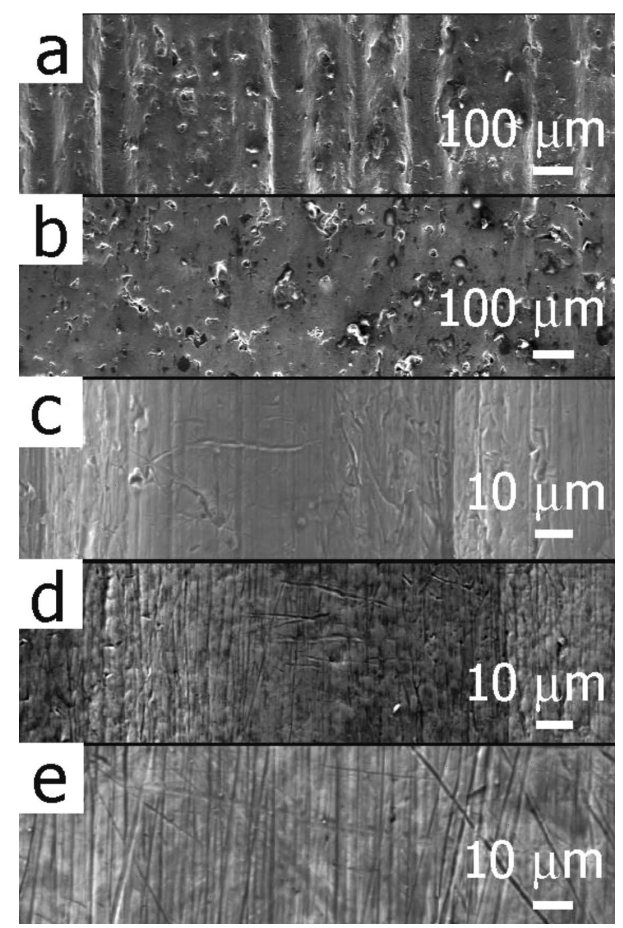

Figure 8: Free surfaces of the samples after the measurement of abrasion resistance: a) plasma-sprayed CP-Al, b) plasma-sprayed aluminium alloy, c) SPS-sintered CP-A1, d) SPS-sintered aluminium alloy, e) uncoated AZ-91 (SEM - SE)

Slika 8: Prosta površina vzorcev po merjenju odpornosti na abrazijo: a) plazemsko nabrizgan $\mathrm{CP}-\mathrm{Al}$, b) plazemsko nabrizgana aluminijeva zlitina, c) SPS sintran CP-al, d9 SPS sintrana aluminijeva zlitina, e) AZ-91 brez nanosa (SEM - SE) spraying technology when used for improving the abrasion resistance.

Table 2: Roughness $R_{\mathrm{a}}(\mu \mathrm{m})$ of the free surfaces of test samples before and during the wear test

Tabela 2: Hrapavost $R_{\mathrm{a}}(\mu \mathrm{m})$ treh prostih površin na preizkušancih, pred in po preizkusu obrabe

\begin{tabular}{|c|c|c|c|c|}
\hline Sample & 0 & $576 \mathrm{~m}$ & $1728 \mathrm{~m}$ & $2304 \mathrm{~m}$ \\
\hline uncoated AZ-91 & 2.3 & 1.9 & 2.0 & 2.4 \\
\hline CP Al-coated AZ-91 & 14.8 & 5.9 & 5.0 & 7.0 \\
\hline Al-alloy coated AZ-91 & 20.2 & 10.6 & 9.0 & 8.2 \\
\hline
\end{tabular}

Table 3: Microhardness of plasma-sprayed layers

Tabela 3: Mikrotrdota plazemsko nabrizganih plasti

\begin{tabular}{|c|c|}
\hline Sample & Microhardness $(\mathrm{HVm})$ \\
\hline CP Al coating & $65 \pm 11$ \\
\hline Al-alloy coating & $223 \pm 48$ \\
\hline Substrate & $120 \pm 42$ \\
\hline
\end{tabular}

Plasma-sprayed CP-Al, Figure 8a, has the surface textured in the direction of the movement of the test (deep vertical grooves). The plasma-sprayed aluminium alloy, Figure $\mathbf{8 b}$, has, thanks to its higher hardness (Table 3), very homogeneous wear damage concentrated only in small areas. The highest weight loss during the wear test was shown on sintered pure aluminium and the uncoated magnesium alloy AZ 91. Their surfaces are displayed in Figures $\mathbf{8 c}$ and 8 e. The surfaces are scratched by the abrasive medium but the damage is very homogeneous. The appearance of the surface of the SPS-sintered aluminum alloy, Figure 8d, is similar.

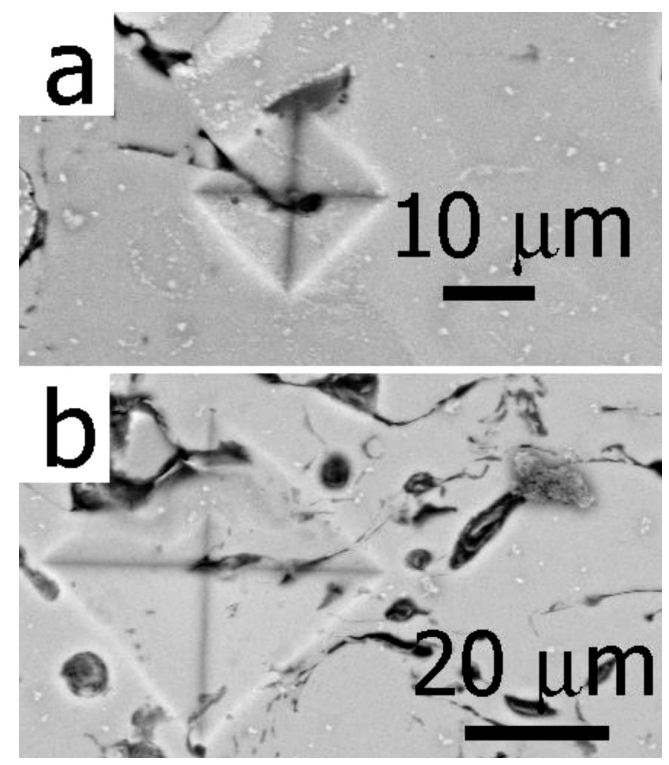

Figure 9: Details of the microstructures of plasma-sprayed layers with indenter imprint after the measurement of microhardness (SEM BSE): a) aluminium alloy, b) CP-aluminium

Slika 9: Detajl mikrostrukture s plazmo nabrizganega sloja, z odtiskom trdote po merjenju mikrotrdote (SEM - BSE): a) aluminijeva zlitina, b) $\mathrm{CP}$-aluminium 


\subsection{Hardness}

The hardness-measurement results are listed in Table $\mathbf{3}$ for the plasma-sprayed layers and the substrate. The measured microhardness values are comparable with the microhardness of the Al coatings deposited with the cold-spray technique. ${ }^{13}$ The average microhardness of the plasma-sprayed aluminium alloy $(223 \mathrm{HVm})$ is nearly four times higher than that of the sprayed $\mathrm{CP}$ aluminium $(65 \mathrm{HVm})$. In reference ${ }^{9}$ dealing with the thermal stability of a similar alloy, a hardness of 160-195 HV is listed. Figure 9 shows micrographs of the indents. In both cases, the coatings are very plastic, without any cracks (in the case of a small load) initiating from the indent corners and also without any distortion of the adjacent pores.

\section{CONCLUSION}

In this work, plasma-sprayed coatings of commercially pure (CP) aluminium and aluminium alloy AlCr6Fe2 were applied on the magnesium alloy AZ 91 by means of a hybrid water-stabilized torch WSP-H $500^{\circ}$. Layers with a thickness of $450 \mu \mathrm{m}$ for CP aluminium and $490 \mu \mathrm{m}$ for the aluminium alloy were prepared. Both obtained plasma-sprayed coatings are relatively inhomogeneous and porous. The micrographs (Figures 3 and 4) show incomplete metallurgical bonds between individual powder particles and molten droplets (splats), respectively. The prepared plasma coatings have a relatively good adhesion, microhardness and abrasion resistance in comparison with the relevant literature. Plasma coating of $\mathrm{CP}$ aluminium showed the average adhesion strength of $19 \mathrm{MPa}$, and the aluminium alloy showed an adhesive strength of $12 \mathrm{MPa}$. During the pull-off test, combined adhesive-cohesive fracture of the CP-aluminum coating occurred. In the case of the aluminium-alloy coating, the whole layer was pulled off, leading to the adhesion mode of failure. The results also clearly show that the abrasion resistance of the plasma-sprayed $\mathrm{CP}$-aluminum coating is better than that of the sintered $\mathrm{CP}$ aluminum. In case of the aluminium alloy, the plasma-sprayed coating and the sintered material have a similar abrasion resistance.

\section{Acknowledgements}

This work was supported by the Czech Science Foundation through the project with number 14-31538P "Evaluation of bonding interface during and after plasma spraying of metallic materials on magnesium and magnesium alloy."

\section{REFERENCES}

${ }^{1}$ D. Votěch, V. Knotek, Magnesium alloys for hydrogen storage, Mater. Tehnol., 46 (2012) 3, 247-250

${ }^{2}$ E. Altuncu, H. Alanyali, The applicability of sol-gel oxide films and their characterisation on a magnesium alloy, Mater. Technol., 48 (2014) 2, 289-292

${ }^{3}$ J. Kubásek, I. Pospíšilová, D. Vojtěch, E. Jablonská, T. Ruml, Structural, mechanical and Cytotoxicity characterization of as-cast biodegradable $\mathrm{Zn}$-xmg ( $\mathrm{x}=0.8-8.3 \%$ ) alloys, Mater. Tehnol., 48 (2014) 5, 623-629

${ }^{4}$ M. Horynová, Fatigue Characteristics of AZ31 magnesium alloy after corrosion degradation, Master's thesis, Brno 2011, 95

${ }^{5}$ M. Qian, D. Li, S.B. Liu, S.L. Gong, Corrosion performance of laser-remelted Al-Si coating on magnesium alloy AZ91D, Corr. Sci., 52 (2010) 10, 3554-3560, doi.org/10.1016/j.corsci.2010.07.010

${ }^{6}$ E. Altuncu, S. Iric, F. Ustel, Wear-resistant intermetallic arc spray coatings, Mater. Tehnol., 46 (2012) 2, 181-183

${ }^{7}$ B. Zou, S. Tao, W. Huang, Z. S. Khan, X. Fan, L. Gu, Y. Wang, J. $\mathrm{Xu}, \mathrm{X}$. Cai, H. Ma, X. Cao, Synthesis and characterization of in situ $\mathrm{TiC}_{-} \mathrm{TiB}_{2}$ composite coatings by reactive plasma spraying on a magnesium alloy, Appl. Surf. Sci., 264 (2014), 879-885, doi.org/10.1016/j.apsusc.2012.10.177

${ }^{8}$ M. Parco, L. Zhao, J. Zwick, K. Bobzin, E. Lugscheider, Investigation of particle flattening behaviour and bonding mechanisms of APS sprayed coatings on magnesium alloys, Surf. Coat. Technol., 201 (2007) 14, 6290-6296, doi.org/10.1016/j.surfcoat.2006.11.034

${ }^{9}$ B. Bártová, D. Vojtěch, J. Verner, A. Gemperle, V. Studnička, Structure and properties of rapidly solidified Al-Cr-Fe-Ti-Si powder alloys, J. Alloy Compd., 387 (2005) 1-2, 193-200

${ }^{10}$ R. Mušálek, M. Vilémová, J. Matějíček, V. Pejchal: MultipleApproach Evaluation of WSP Coatings Adhesion/Cohesion Strength, Proc. from the Int. Thermal Spray Conference and Exposition, Houston, 2012, 746-751

${ }^{11}$ T. F. Kubatík, Z. Pala, P. Novák, Compacting the powder of Al-Cr-Mn alloy with SPS, Mater. Tehnol., 49 (2015) 1, 129-132

${ }^{12}$ US Standard ASTM G 75-95: Standard Test Method for Determination of Slurry Abrasivity (Miller number) and Slurry Abrasion Response of Materials (SAR number), ASTM International, West Conshohocken, PA, United States, 1995

${ }^{13}$ B.T. Sofyan, D. Satiti, E. Pereloma, Characteristics of Cold Spray Aluminium Coating on ZE41A-T5 Magnesium, AA7075 Aluminium, and 4130 Steel Substrates: Proc. Int. Conf. Materials and Metallurgical Tech., Surabaya, 2009, 99-103 